\title{
Do LPG Prices React to the Entry of Natural Gas? Implications for Competition Policy
}

\author{
Autores: \\ Aldo González \\ Vicente Lagos
}




\title{
Do LPG Prices React to the Entry of Natural Gas? Implications for Competition Policy
}

\author{
Aldo González ${ }^{1}$ \\ Vicente Lagos ${ }^{2}$ \\ Working Paper, April 2019
}

\begin{abstract}
In developing countries, the penetration of Liquefied Petroleum Gas (LPG) is still high, and hence the entry of Natural Gas (NG) networks coexists with the use of LPG by an important fraction of households. Thus, a relevant policy question is whether the number and degree of horizontal integration among NG and LPG providers has an influence on the level of retail prices. Using selfreported LPG retail prices of the largest LPG provider in Chile for the period 2013-2014, we estimate that the presence of a competing NG network generates an average decrease of LPG retail prices within the range $[-2,-4 \%]$ depending on the econometric specification. Thus, since the presence of an additional competing provider (i.e., an NG retailer) has an influence on the level of prices, LPG and NG may be indeed considered as imperfect substitutes. The main policy implication of this result is that the degree of horizontal integration between both types of providers should matter and there would be room for regulatory intervention aimed at proposing remedies in order to mitigate any potential anticompetitive effect
\end{abstract}

Keywords Entry, Horizontal Integration, Liquefied Petroleum Gas, Natural Gas, Retail Market JEL classification K21, L13, L41, L95, Q41

\footnotetext{
* We are very thankful to Mattia Nardotto, Christine Zulehner, Marc Ivaldi and Daniel Herrera, for insightful advice and comments on an earlier version of the paper. In addition, the paper has benefited from interesting discussions with participants at the 2017 Eurasian Conference organized by the International Association for Energy Economics (IAEE), and at the 2017 LACEA-LAMES conference organized by the University of San Andres in Buenos Aires.

${ }^{1}$ Department of Economics, Universidad de Chile, email: agonzalez@econ.uchile.cl.

${ }^{2}$ Corresponding Author:

Department of Social Sciences and Economics, Télécom ParisTech, email: vicente.lagostoro@telecomparistech.fr.
} 


\section{Introduction}

If natural gas (NG) and liquefied petroleum gas (LPG) are imperfect substitutes, there is a relevant implication for public policy, that is to say, the degree of horizontal integration between NG and LPG providers should have an impact on the level of equilibrium market prices. Thus, in a context of oligopolistic competition, there would be room for regulatory intervention aimed at evaluating the impact of horizontal integration on prices and at proposing remedies in order to mitigate any potential anticompetitive effect.

This issue is particularly relevant for developing countries, where the penetration of LPG is still high, and hence the entry of NG networks coexists with the use of LPG by an important fraction of households. For instance, in Chile $90 \%$ of households would have access to LPG. ${ }^{34}$ In this context, the aim of this paper is to empirically assess whether the presence of an NG provider in a particular geographic market has an impact on LPG retail prices. This exercise represents an indirect test of the degree of substitutability between NG and LPG, and of the potential anticompetitive effects that could emerge from the existence of horizontal integration between both types of providers. On the one hand, if NG and LPG are perfect substitutes, the equilibrium market price should be equal to the marginal cost of the product with the least efficient technology of distribution, i.e., the LPG. In this scenario the retail price of NG should follow the retail price of LPG, and hence NG entry should not have any impact on prices (as long as there are at least two independent competing LPG providers). On the other hand, if NG and LPG are imperfect substitutes, the number of competitors in the market should matter, and thus the presence of an NG provider should generate a decrease of LPG retail prices. In addition, in an

\footnotetext{
3 Financial statements of Lipigas (i.e., the largest LPG provider of the country) for 2018 (source: https://www.lipigas.com/wp-content/uploads/2019/04/Memoria-Lipigas abril-2018-1.pdf)

${ }^{4}$ According to Kojima et al. (2011), in 2011 the percentage of households using LPG in Brazil, Mexico and Peru, was equal to $88 \%, 80 \%$ and $63 \%$, respectively. Similarly, in 2017 the South African Competition Commission published a report of a market inquiry carried out on the LGP sector in that country. Among other things, the report shows that: (i) the GLP distribution by cylinders is particularly important for poorer households, and (ii) due to the lack of NG networks in many regions of the country, competition between LPG and NG providers would be rather limited.
} 
imperfect competition setting, the degree of horizontal integration among competitors matters, because the level of equilibrium prices is affected by this variable. ${ }^{5}$

Using data of monthly retail prices at the municipality level self-reported by retail gas providers in Chile during the period January 2013 - December 2014, we measure the impact of the presence of an NG network on LPG retail prices. Note that the Chilean case is particularly interesting because during the period 2014-2018, the Chilean Competition Tribunal (CCT) carried out a competition assessment review of this industry. The main purpose of the CCT was to evaluate whether the structure of the industry, both in terms of horizontal and vertical integration, could potentially lead to a softening of competition among LPG and NG providers. Notably, before 2016 the main three LPG providers of the country shared the property of Metrogas, the largest NG network of the country. ${ }^{6}$

We run simple cross-section Ordinary Least Squares (OLS) regressions comparing retail prices among municipalities with and without presence of an NG provider, taking advantage of the fact that the largest LPG provider in the country mostly sets different prices for different municipalities. Our results suggest that the presence of an NG provider generates a reduction of LPG retail prices of about $-2 \%$ on average. However, since the NG entry decision in a given municipality is endogenous, this simple cross-section OLS comparison is likely to result in a biased estimator of the impact of entry on prices. On the one hand, if entry occurred mainly in highly profitable markets, then is likely to observe a positive bias in the estimation of the impact of entry on the level of retail prices. In contrast, if entry occurred mainly in markets with lower fixed and variable costs of distribution, then is likely to observe a negative bias.

To address this endogeneity issue, we implement an Instrumental Variables (IV) approach. Our methodology closely follows the IV approach used by Berry and Waldfogel (1999), who estimate the impact of public radio stations 'entry on commercial stations` listening shares. This methodology is also similar to the control function approach

\footnotetext{
${ }^{5}$ See for instance Brito, Ribeiro and Vasconcelos (2014) who propose an empirical methodology to evaluate the unilateral effects of partial horizontal acquisitions.

${ }^{6}$ However, during the second half of 2016, Gasco (the controlling shareholder) decided to sell its participation on Metrogas.
} 
proposed by Nardotto, Valletti and Verboven (2015), who estimate the impact of local loop unbundling on broadband penetration in the UK. ${ }^{7}$ In line with both Berry and Waldfogel (1999) and Nardotto et al. (2015), we use market size as the main instrument for entry. ${ }^{8}$ Indeed, considering that the deployment of an NG distribution network requires the entrant to incur in large fixed costs, NG entry should be profitable only in markets in which is possible to reach a certain minimum scale of operation. Thus, market size (in terms of number of households) should be a good predictor of entry. In addition, since market size should not a priori affect the price-sensitivity of a given household, price elasticities and equilibrium prices should be independent of this variable (see Berry and Waldfogel 1999, for a similar exposition of this assumption).

The resulting IV estimates suggest a reduction of LPG retail prices of about $-4 \%$ on average, as a result of the presence of a NG competing provider in a given municipality. Thus, this estimated effect is found to be higher (in absolute terms) than the one estimated by OLS. This evidence suggests that the bias generated by the endogeneity of entry has a positive sign, leading to an underestimation of the impact of entry on LPG prices by OLS. ${ }^{9}$ In other words, the positive sign of the bias suggests that entry of NG providers has been mainly motivated by profitability considerations. Our results are robust to the use of the average per capita income in a given municipality as an instrument for NG entry, and to the exclusion of the municipalities from the Metropolitan Region (where the competing NG network sets significantly lower prices than NG providers operating in other regions).

The main policy implication of our results is that, since the presence of an NG competing provider has an impact on the level of retail prices, competition between both LPG and NG providers seems to take place in a setting of imperfect competition. In this setting, the degree of horizontal integration between LPG and NG competing networks should also have influence the level of retail prices, and hence, there would be room for

\footnotetext{
${ }^{7}$ Note that, as pointed out by Nardotto et al. (2015), the control function approach is essentially equivalent to an IV estimator. In our case, a control function approach would consider in a first stage an entry model using market size as the main entry determinant for NG. In a second stage, the impact of NG entry on LPG prices would be estimated using the output of the first stage as a correction term in the pricing equation.

${ }^{8}$ In addition, Nardotto et al. (2015) also consider several fixed cost determinants as exclusion restrictions to identify the effects of local loop unbundling entry.

${ }^{9}$ Berry and Waldfogel (1999) find the same sign for the OLS bias.
} 
competition authorities to evaluate the potential anticompetitive unilateral and coordinated effects of mergers and partial horizontal acquisitions between both types of providers.

This paper contributes to a strand of empirical literature that estimates the impact of market structure on gas prices. In this vein, Hulshof, Van der Maat and Mulder (2016) analyze the day-ahead spot price of NG at the Dutch gas hub over the period 2011-2014. These authors focus on the north-west European market (i.e., Austria, Belgium, Denmark, France, Germany, Italy, the Netherlands and the UK), and find that changes in the concentration on the supply side do not affect the movement in gas prices. Similarly, other articles studying the effects of supply and demand side fundamentals on gas prices are Mu (2007) and Brown and Yücel (2008). However, to the best of our knowledge there are no papers studying the impact of NG presence on LPG retail prices. Note that this question is particularly relevant for developing countries, where the recent deployment of NG networks coexists with the use of LPG by an important fraction of households.

Section 2 contains a brief description of the retail gas industry in Chile. Section 3 describes the data used in the paper. Section 4 introduces the empirical approach, and Section 5 summarizes our main findings. Finally, Section 6 presents the main conclusions of the paper.

\section{The Gas Industry in Chile}

There are three retail providers of LPG in Chile, their brands are: Lipigas (38\% market share), Abastible (35\% market share) and Gasco (27\% market share) and. ${ }^{10}$

Regarding the NG market, Table 1 summarizes the identity of NG retail providers in the country, the region in which they operate, and their degree of horizontal integration with LPG providers, prior to the year 2015. Note that in general, the number of NG

\footnotetext{
${ }^{10}$ All market shares measured in 2011 (source: https://www.wlpga.org/wp-content/uploads/2015/09/Chile Angel Carabias_ouniaux GLP Chile.pdf). Similarly, the Chilean Competition Tribunal (CCT) mentions that by 2014 the market shares of Lipigas, Abastible and Gasco were equal to $37 \%, 36.7 \%$ and $26.6 \%$, respectively (source: https://www.tdlc.cl/nuevo tdlc/wp-content/uploads/resoluciones/Resoluci\%C3\%B3n-51-2018.pdf).
} 
providers per municipality is equal to zero or one; there is only one exception in which there are two NG providers in the same municipality. ${ }^{11}$ As it can be seen in the table, before 2015 there was an important degree of horizontal integration among NG and LPG providers. In particular, the most relevant case was Metrogas, the largest NG network in the country which was horizontally integrated with the three LPG providers. However, only Gasco had the corporate control over Metrogas, while both Abastible and Lipigas were minority shareholders.

During the past two years, there has been entry of NG providers in more municipalities. However, with the exception of the municipality of Temuco, entry in these locations is still incipient as it has not covered yet a relevant share of the population in these markets (see Table 2 below). In addition, and more importantly, new entry is expected in the near future. In particular, both Metrogas and Lipigas have recently announced their intention to enter in several regions of the country. For instance, in the case of Metrogas, its expansion plan intends to connect 800,000 additional households into its network.

Table 1 - Horizontal integration between LPG and NG providers (prior to 2015)

\begin{tabular}{|c|c|c|c|c|}
\hline Region of Chile & NG provider & $\begin{array}{l}\text { Related LPG provider } \\
\quad \text { (prior to 2015) }\end{array}$ & $\begin{array}{c}\text { Number of clients by } \\
\text { region }(2017)\left(^{*}\right)\end{array}$ & $\begin{array}{c}\text { Number of } \\
\text { municipalities served } \\
\text { by region }\left(2017()^{*}\right)\end{array}$ \\
\hline Region II & Lipigas GN & Lipigas (100\%) & 3,294 & 1 \\
\hline Region V & GasValpo & None & 94,547 & 12 \\
\hline $\begin{array}{l}\text { Metropolitan } \\
\text { Region }\end{array}$ & Metrogas & $\begin{array}{c}\text { Gasco }(51.84 \%) \\
\text { Abastible }\left(39.83 \%^{12}\right) \text { and } \\
\text { Lipigas }\left(8.33 \%{ }^{13}\right)\end{array}$ & 539,352 & 40 \\
\hline Region VIII & $\begin{array}{l}\text { GasSur } \\
\text { Intergas }\end{array}$ & Gasco $100 \%$ & 37,047 & 7 \\
\hline Region XII & Gasco Magallanes & Gasco $(100 \%)$ & 51,840 & 3 \\
\hline
\end{tabular}

$\left.{ }^{*}\right)$ Source: Superintendencia de Electricidad y Combustibles

\footnotetext{
${ }^{11}$ Los Angeles, located in the Region VIII of Chile

12 The group Empresas Copec owns Abastible and has the $39.83 \%$ of the shares of Metrogas.

13 The group Lipigas owned Trigas, and before 2015 Trigas had the $8.33 \%$ of the shares of Metrogas.
} 
Table 2 - NG entry after 2015

\begin{tabular}{cccc}
\hline NG provider & Municipality & $\begin{array}{c}\text { Number of } \\
\text { clients 2017 }\left(^{*}\right)\end{array}$ & Penetration $^{14}$ \\
\hline Metrogas & Machali & 653 & $5.01 \%$ \\
& Rancagua & 1,559 & $2.69 \%$ \\
GasValpo & Coquimbo & 9 & $0.02 \%$ \\
& La Serena & 451 & $0.91 \%$ \\
& Los Andes & 105 & $0.62 \%$ \\
Intergas & Talca & 358 & $0.59 \%$ \\
\hline \multicolumn{2}{c}{$\left(^{*}\right)$ Source: Superintendencia de Electricidad y Combustibles }
\end{tabular}

Recently, during the period 2014-2018, the Chilean Competition Tribunal (CCT) carried-out a competition assessment review regarding the potential anticompetitive effects of horizontal and vertical integration within the LPG and NG industries. In this context, during the second half of year 2016 Gasco sold its share on Metrogas to Gas Natural Fenosa, Spanish Group specialized in the natural gas sector. In addition, Lipigas also sold its share on Metrogas. Both transactions significantly decreased the level of horizontal integration in this industry. ${ }^{15}$

\section{The Data}

We use data from a website launched by the Chilean Energy Regulator (i.e., Comisión Nacional de Energía), in which all gas providers in Chile must report the monthly bill of natural gas paid by a representative household (i.e., http://gasdered.cne.cl/). ${ }^{16}$ Table 3 displays basic summary statistics for years 2013-2014. As shown in the table, Gasco is the most expensive brand. Abastible and Lipigas seem to be cheaper and to set more similar prices between them, but there is still some degree of differentiation. This is confirmed by

\footnotetext{
${ }^{14}$ Considering the population growth forecasts elaborated by the Chilean Statistics Institute (i.e., INE) for year 2017, and the average household size per municipality extracted from a representative household survey during the year 2013 (i.e., CASEN).

${ }^{15}$ Nevertheless, as we mentioned before, Lipigas has recently announced its intention to expand its business to the retail distribution of NG in several regions of the country.

16 In practice, the representative household bill is computed as the retail price of $8 \mathrm{~m} 3$ of LPG or equivalently $19.3 \mathrm{~m} 3$ of $\mathrm{NG}$
} 
the histogram graph in Panel a) of Figure 1. Note that the fact that different LPG providers have different pricing strategies supports the hypothesis of imperfect competition in the market.

Table 3 - Summary Statistics

\begin{tabular}{ccccccc}
\hline Price & $\begin{array}{c}\text { Num. of } \\
\text { Municipalities }\end{array}$ & Num. of Obs. $\left(^{*}\right)$ & Mean & Std. Dev. & Min. & Max. \\
\hline Abastible & 318 & 7,632 & 57,699 & 4,701 & 46,359 & 71,720 \\
Gasco & 120 & 2,808 & 66,925 & 4,153 & 57,339 & 81,553 \\
Lipigas & 123 & 2,952 & 58,505 & 5,259 & 43,484 & 70,663 \\
\hline
\end{tabular}

$\left(^{*}\right)$ Each observation corresponds to a municipality-month combination, for the years 2013 and 2014

Panel b) of Figure 1, contains a histogram graph that displays the retail prices of all LPG brands combined, distinguishing municipalities with and without NG entry. As shown, a priori prices do not seem to be significantly different in the presence of an NG provider. However, when distinguishing the histogram of prices by brand (see Figure A.1 in the Appendix), it seems that LPG retail prices are lower in the presence of an NG provider at least for the case of Abastible and to a lesser extent for the case of Lipigas. But note that since entry is determined by profitability and/or cost considerations that may at the same time have an influence on the level of prices, a simple correlation between both variables is not necessarily informative of the causal impact of NG entry on prices. 
Panel a) LPG prices by brand $(*)\left({ }^{* *}\right)$

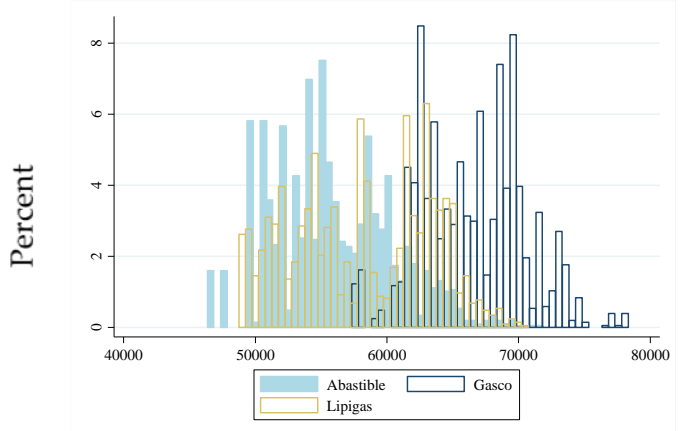

Retail price (Chilean pesos)
Panel b) LPG prices by municipalities with and without NG presence $\left(^{*}\right)\left({ }^{* *}\right)$

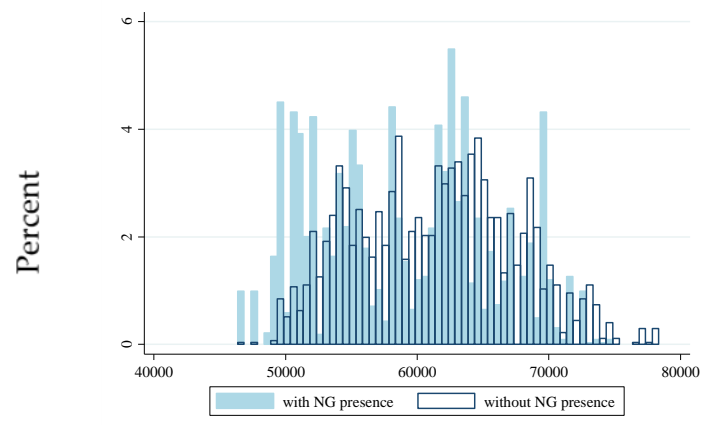

Retail price (Chilean pesos)

$\left.{ }^{*}\right)$ The graph only considers municipalities in which the three LPG providers are simultaneously present (January 2013 - December 2014)

$\left.{ }^{* *}\right)$ Each observation corresponds to a municipality-month combination, for the years 2013 and 2014

Figure 1 - Comparison of prices across competitors and municipalities (LPG)

As we will explain in the next section, our identification strategy is based on the fact that LPG retailers may set different prices in different municipalities according to differences in local demand and supply conditions. Thus, the basic idea is to compare LPG retail prices in between municipalities with and without the presence of a competing NG provider. However, as Table 4 shows, only Lipigas seems to set differentiated prices across municipalities (this table exhibits the number of different prices that each brand sets in and out of the Metropolitan Region, i.e., the capital city Santiago and its suburbs). As shown, Gasco and Abastible seem to use a regional pricing (or at least this is what they report), setting a single price for municipalities that belong to the Metropolitan Region and setting between thirteen and seventeen different prices for the municipalities out of the Metropolitan Region (and note that Chile is divided into sixteen administrative regions). For this reason, in the rest of the paper we will only consider Lipigas LPG retail prices. Figures A.2 and A.3 in the Appendix contain histograms of retail prices set by this brand in and out of the Metropolitan Region, and they suggest that prices indeed vary across municipalities. 
Table 4 - Degree of price differentiation across municipalities

\begin{tabular}{|c|c|c|c|c|c|c|c|}
\hline \multirow{2}{*}{\multicolumn{2}{|c|}{ Variable }} & \multicolumn{2}{|c|}{ Abastible } & \multicolumn{2}{|c|}{ Gasco } & \multicolumn{2}{|c|}{ Lipigas } \\
\hline & & $\begin{array}{c}\text { Metropolitan } \\
\text { Region }\end{array}$ & $\begin{array}{c}\text { Other } \\
\text { Regions }\end{array}$ & $\begin{array}{l}\text { Metropolitan } \\
\text { Region }\end{array}$ & $\begin{array}{c}\text { Other } \\
\text { Regions }\end{array}$ & $\begin{array}{c}\text { Metropolitan } \\
\text { Region }\end{array}$ & $\begin{array}{c}\text { Other } \\
\text { Regions }\end{array}$ \\
\hline $\begin{array}{r}\text { Total nu } \\
\text { munici }\end{array}$ & $\begin{array}{l}\text { per of } \\
\text { lities }\end{array}$ & 52 & 266 & 40 & 77 & 37 & 86 \\
\hline \multirow{12}{*}{$\begin{array}{c}\text { Number of } \\
\text { different } \\
\text { prices }\end{array}$} & Jan-14 & 1 & 17 & 1 & 14 & 10 & 43 \\
\hline & Feb-14 & 1 & 16 & 1 & 13 & 9 & 45 \\
\hline & Mar-14 & 1 & 17 & 1 & 14 & 6 & 38 \\
\hline & Apr-14 & 1 & 17 & 1 & 14 & 6 & 38 \\
\hline & May-14 & 1 & 17 & 1 & 14 & 6 & 38 \\
\hline & Jun-14 & 1 & 17 & 1 & 14 & 6 & 39 \\
\hline & Jul-14 & 1 & 17 & 1 & 14 & 6 & 39 \\
\hline & Aug-14 & 1 & 17 & 1 & 14 & 6 & 46 \\
\hline & Sep-14 & 1 & 17 & 1 & 14 & 5 & 44 \\
\hline & Oct-14 & 1 & 17 & 1 & 14 & 6 & 46 \\
\hline & Nov-14 & 1 & 16 & 1 & 14 & 6 & 48 \\
\hline & Dec-14 & 1 & 17 & 1 & 14 & 6 & 46 \\
\hline
\end{tabular}

Finally, regarding the pricing of NG providers, Figure 2 below displays the histogram of prices distinguishing Metrogas (i.e., the NG provider in the Metropolitan Region) and other providers in other regions. As shown, prices of Metrogas are significantly lower.

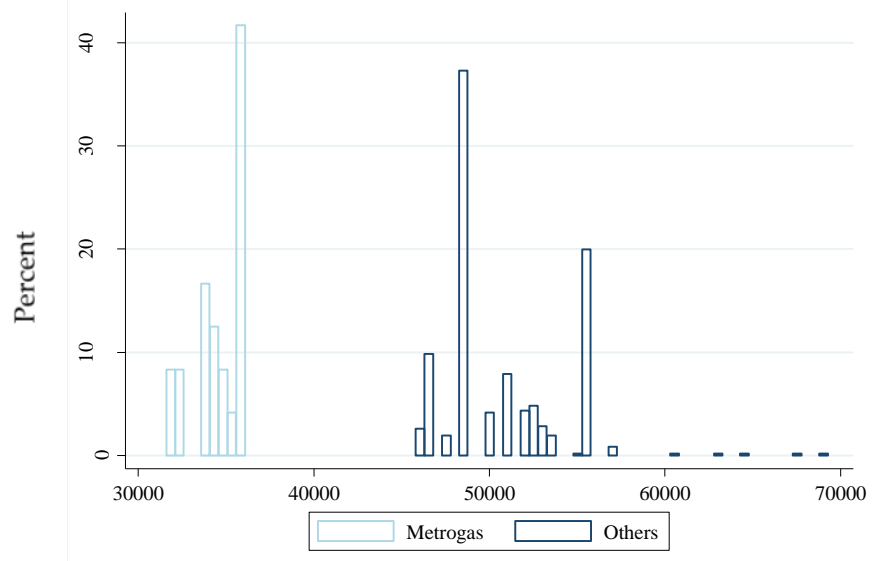

Retail Price (Chilean Pesos)

Figure 2 - Comparison of prices across competitors and municipalities (NG) 


\section{Empirical Approach}

In a context of perfect competition between LPG and NG providers, the equilibrium price should be equal to marginal cost of distribution of the operator with the less efficient technology. Therefore, in this scenario the NG retail price should follow the LPG retail price, and entry should not have any impact on prices. ${ }^{17}$ However, in a context of oligopolistic competition, the number of competitors and their degree of horizontal integration should matter, and hence different market structures should lead to different levels of equilibrium prices. Thus, our purpose is to empirically test whether the presence of an NG network in a given municipality is associated with significantly lower LPG retail prices or not. This test will provide us with indirect evidence of the degree of substitutability between LPG and NG.

\subsection{Cross-section analysis by OLS}

We compare LPG retail prices in communes with and without presence of an NG provider, by simply regressing prices (i.e., the dependent variable) on a set of explanatory variables, including a dummy that takes the value of 1 (one) when there is presence of an NG provider in a given municipality and 0 (zero) otherwise. Evidently, since entry is endogenous this simple analysis is likely to result in a biased estimator of the impact of entry on prices. On the one hand, if NG entry mainly occurs in markets in which consumers have higher willingness to pay, then it is likely to observe a positive bias in the estimation of NG entry on LPG retail prices. However, on the other hand, if entry mainly occurs in markets with lower fixed and variable costs of production/distribution, then the bias is likely to display a negative sign.

We use as controls the number of LPG providers per municipality, and the distance of each municipality with respect to the Port of Quintero, which by years 2013 and 2014

\footnotetext{
17 We assume that the marginal cost of distributing LPG is higher than the marginal cost of distributing NG. Indeed, while the LPG is mainly distributed by trucks, NG is distributed by pipelines.
} 
was the main distribution point of LPG and NG at the wholesale level. As shown in Figure 3, this latter variable seems to be an accurate predictor of the level of retail prices per municipality. There are only two outlier observations that are located relatively far away from the port and for which the average price is considerably low (i.e., Arica and Calama).

The following basic pricing equation is estimated through OLS:

$$
\ln \left(\text { price }_{i}\right)=\beta_{0}+\beta_{1} n_{-} L P G_{i}+\beta_{2} N G_{i}+\beta_{3} \text { dist_port }_{i}+\mu_{i}
$$

where price $_{i}$ represents the mean retail price of Lipigas in municipality $i$ during years 2013 and 2014. Moreover, $n_{-} L P G_{i}$ is the number of LPG providers in municipality $i$, and $d_{i s t}$ port $_{i}$ is the distance between municipality $i$ and Quintero port (measured in $200 \mathrm{~km}$. units). Our main variable of interest is $N G_{i}$, which is a dummy variable that takes the value of 1 (one) if municipality $i$ has an NG network before year 2014, and takes the value of 0 (zero) otherwise.

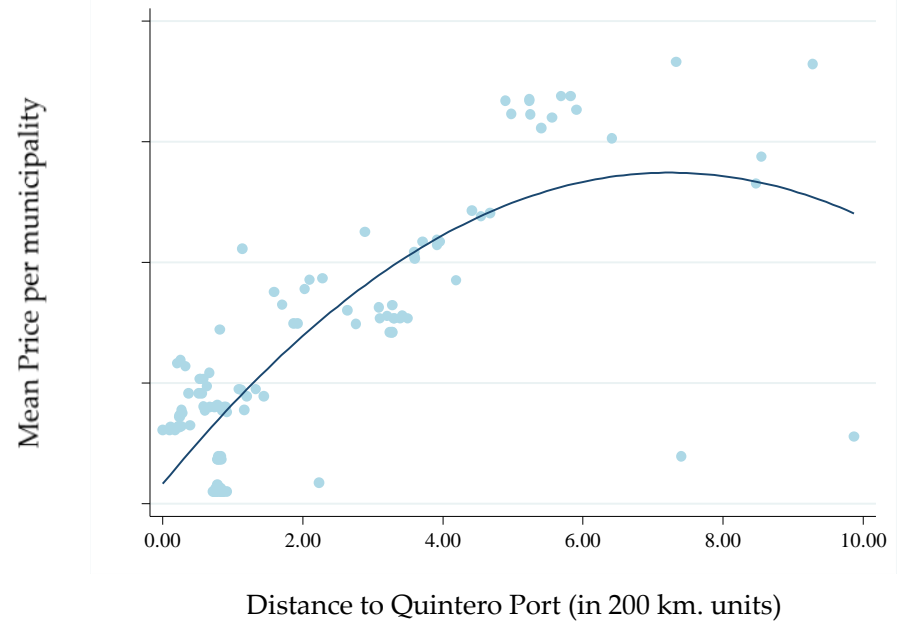

Figure 3 - Scatter graph between the average LPG retail price per municipality during years 20132014 and distance to Quintero port (for Lipigas) 


\subsection{Entry determinants as instrumental variables}

We implement an empirical approach similar to the one used by Berry and Waldfogel (1999), who use instrumental variables (IV) to estimate the impact of public radio stations' entry on commercial stations' listening shares, using different measures of market size as instruments. The validity of the IV approach in this case relies on the assumption that while market size has a direct influence on entry, it does not necessarily affect listening shares. Similarly, Nardotto, Valletti and Verboven (2015) use a control function approach to estimate the impact of local loop unbundling on broadband penetration in the UK. In a first stage, they estimate an entry model using market size as one of the main determinants of entry. In a second stage, the output of the first stage (i.e., the inverse Mills ratio) is used as an additional control in the regression that measures the impact of local loop unbundling entry on certain measures of market performance. ${ }^{18}$ Note that, as pointed out by Nardotto et al. (2015), the control function approach is essentially equivalent to an IV regression.

Thus, we use market size as the main instrument for NG entry, and estimate its impact on retail prices through an IV model. Similarly to Berry and Waldfogel (1999), the underlying assumption that supports the use of market size as instrument, is that while this variable has a direct effect on entry, it does not necessarily influences the level of retail prices. In order to present the intuition behind this assumption, we can consider for instance the following profit function:

$$
\pi_{i, m}=\left(p_{i, m}-c_{i, m}\right) \times q_{i, m}\left(p_{i, m}, p_{-i, m}\right) \times s_{m}-F_{i . m}
$$

where $\pi_{i, m}$ represents the profit of gas retailer $i$ (either an LPG or an NG provider) in municipality $m$. In turn, variables $p_{i, m}$ and $c_{i . m}$ are the price and constant marginal cost of distribution of firm $i$ in market $m$. Note that marginal costs may differ across firms (e.g.,

\footnotetext{
18 The entry model proposed by Nardotto et al. (2015) closely follows the entry model introduced by Bresnahan and Reiss (1991). In addition, the control function approach is based on Heckman (1979) and Manuszak and Moul (2008).
} 
due to different levels of efficiency) and across markets (e.g., due to different distances to the port of supply of liquefied gas). In addition, $q_{i, m}$ represents the market share of firm $i$ in market $m$, which is a function of the prices charged by firm $i$ (i.e., the variable $p_{i, m}$ ) and by the prices charged by its competitors (i.e., the vector of prices $p_{-i, m}$ ). Finally, the variable $s_{m}$ is the size of municipality $m$ and $F_{i, m}$ is the fixed cost of deployment of the distribution network of firm $i$ in municipality $m$.

From Equation (2), it is straightforward to show that the first order condition (FOC) of the profit maximization decision faced by firm $i$, which in turns represents its price bestresponse function (i.e., $\left.p_{i, m}=f\left(p_{-i, m}, c_{i, m}\right)\right)$, does not depend on the size of the market. Indeed, equilibrium prices are determined by firms' marginal costs of production and by their own-price elasticities. ${ }^{19}$ However, the entry decision of firm $i$ in municipality $m$, it is certainly influenced by $s_{m}$, as this term is part of its profit function and it has a direct impact on the probability of entry. ${ }^{20}$

In practice, we measure market size as the size of the population per municipality during the year 2012. ${ }^{21}$ As shown in Panel a) of Figure 3, is clear that entry of an NG provider occurs mainly in municipalities with large populations. In addition, we also consider the average per capita income by year 2013 as an entry determinant. ${ }^{22}$ Depending on the specification, the population size and/or income variables will only appear as instruments, thus serving as exclusion restrictions to identify the impact of the presence of an NG network on prices. As shown in Panel b) of Figure 3, a priori population size does not seem to be a good predictor of the level of retail prices, which supports its exclusion from the second stage equation.

${ }^{19}$ This FOC is equal to $\partial \pi_{i, m} / \partial p_{i, m}=\left(p_{i, m}-c_{i, m}\right) \partial q_{i, m}\left(p_{i, m}, p_{-i, m}\right) / \partial p_{i, m}+q_{i, m}\left(p_{i, m}, p_{-i, m}\right)=0$. Equivalently,

this equation can also be expressed as $\left(p_{i, m}-c_{i, m}\right) / p_{i, m}=1 / \eta_{i, m}\left(p_{i, m}, p_{-i, m}\right)$, where $\eta_{i, m}$ represents the own-price elasticity of product $i$ in market $m$.

${ }^{20}$ Indeed, for entry to be profitable, the following condition must be satisfied:

$$
\pi_{i, m}=\left(p_{i, m}-c_{i, m}\right) \times q_{i, m}\left(p_{i, m}, p_{-i, m}\right) \times s_{m}-F_{i, m}>0
$$

${ }^{21}$ Population size and growth projections are made the Instituto Nacional de Estadisticas (INE).

22 This information is extracted from a representative household survey called CASEN (year 2013). We measure income in units of 70,000 Chilean Pesos (approximately 100 US dollars). 
Panel a) Entry

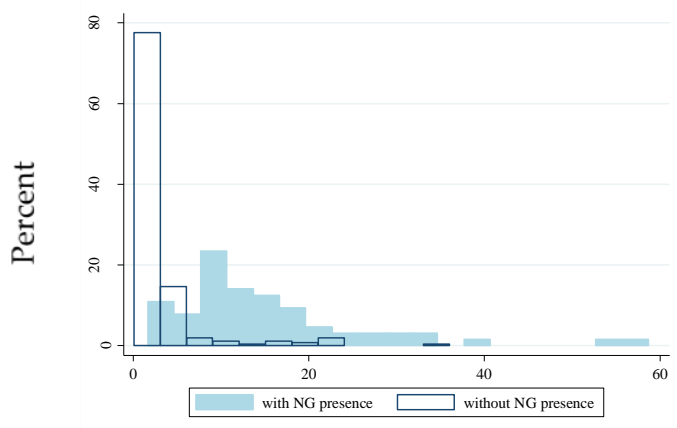

Population size (in 10.000 habitants units)
Panel b) Prices

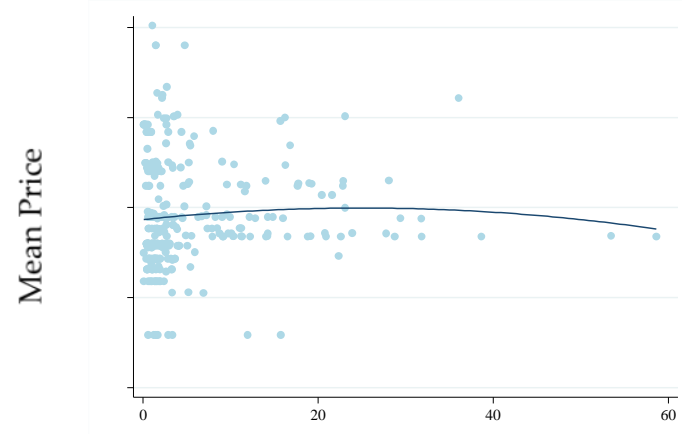

Population size (in 10.000 habitants units)

Figure 4 - Population size, entry and prices (all municipalities in the sample)

\section{Results}

\subsection{Results from the cross-section analysis}

Table 5 summarizes the results of a set of simple OLS regressions of Equation $1 .{ }^{23}$ Results suggest that the presence of an NG provider in a given commune generates a significant decrease of LPG retail prices of about $-2 \%$ on average (Columns 1 and 2). As a robustness check, we re-estimated the model incorporating per capita income as an explanatory variable (Columns 3 and 4). Results are very similar in terms of signs and magnitudes. However, contrary to what we would have expected, the coefficient of income displays a negative sign. One potential explanation for this result is the fact that income may be a determinant of entry, which in turn would imply that both variables (income and entry) are positively correlated. For this reason, in the next section in addition to population size we will also use income as an instrument to control for the endogeneity of NG entry. Finally, as a second robustness check, we re-estimated the model excluding the two

\footnotetext{
${ }^{23}$ In the original database Lipigas reports prices on 123 different municipalities. However, we excluded "Farellones", "Linderos" and "Llolleo" because these locations are not actual municipalities, and thus we could not match them with our income and distance datasets.
} 
municipalities that seem to be outliers in Figure 2 (i.e., Arica and Calama) and results are very similar (Columns 4 to 8 ).

Table 5 - Cross section analysis with OLS regression (Lipigas prices only)

\begin{tabular}{|c|c|c|c|c|c|c|c|c|}
\hline VARIABLES & $\begin{array}{c}(1) \\
\ln (\text { price }) \\
\end{array}$ & $\begin{array}{c}(2) \\
\ln (\text { price }) \\
\end{array}$ & $\begin{array}{c}(3) \\
\ln (\text { price })\end{array}$ & $\begin{array}{c}(4) \\
\ln (\text { price }) \\
\end{array}$ & $\begin{array}{c}(5) \\
\ln (\text { price }) \\
\end{array}$ & $\begin{array}{c}(6) \\
\ln (\text { price }) \\
\end{array}$ & $\begin{array}{c}(7) \\
\ln (\text { price }) \\
\end{array}$ & $\begin{array}{c}(8) \\
\ln (\text { price }) \\
\end{array}$ \\
\hline$N G$ & $\begin{array}{l}-0.0268^{* * *} \\
(0.00421)\end{array}$ & $\begin{array}{c}-0.0229^{* * *} \\
(0.00357)\end{array}$ & $\begin{array}{c}-0.0258^{* * *} \\
(0.00432)\end{array}$ & $\begin{array}{c}-0.0225^{* * *} \\
(0.00367)\end{array}$ & $\begin{array}{l}-0.0211^{* * *} \\
(0.00249)\end{array}$ & $\begin{array}{c}-0.0201^{* * *} \\
(0.00220)\end{array}$ & $\begin{array}{c}-0.0201^{* * *} \\
(0.00254)\end{array}$ & $\begin{array}{c}-0.0193^{* * *} \\
(0.00233)\end{array}$ \\
\hline$n_{-} L P G$ & $\begin{array}{c}0.00292 \\
(0.00377)\end{array}$ & $\begin{array}{c}0.00180 \\
(0.00403)\end{array}$ & $\begin{array}{c}0.00348 \\
(0.00376)\end{array}$ & $\begin{array}{c}0.00209 \\
(0.00404)\end{array}$ & $\begin{array}{l}0.000625 \\
(0.00363)\end{array}$ & $\begin{array}{l}0.000368 \\
(0.00339)\end{array}$ & $\begin{array}{c}0.00122 \\
(0.00363)\end{array}$ & $\begin{array}{l}0.000880 \\
(0.00339)\end{array}$ \\
\hline dist_port & $\begin{array}{c}0.00914^{* * *} \\
(0.00181)\end{array}$ & $\begin{array}{l}0.0194^{* * *} \\
(0.00332)\end{array}$ & $\begin{array}{c}0.00921^{* * *} \\
(0.00182)\end{array}$ & $\begin{array}{l}0.0193^{* * *} \\
(0.00338)\end{array}$ & $\begin{array}{c}0.0119^{* * * *} \\
(0.000917)\end{array}$ & $\begin{array}{l}0.0152^{* * *} \\
(0.00177)\end{array}$ & $\begin{array}{c}0.0120^{* * *} \\
(0.000893)\end{array}$ & $\begin{array}{l}0.0151^{* * *} \\
(0.00177)\end{array}$ \\
\hline dist_port ${ }^{2}$ & & $\begin{array}{l}-0.00132^{* *} \\
(0.000545)\end{array}$ & & $\begin{array}{l}-0.00131^{* *} \\
(0.000556)\end{array}$ & & $\begin{array}{l}-0.000470^{*} \\
(0.000277)\end{array}$ & & $\begin{array}{l}-0.000437 \\
(0.000277)\end{array}$ \\
\hline income & & & $\begin{array}{c}-0.000737^{* *} \\
(0.000363)\end{array}$ & $\begin{array}{l}-0.000360 \\
(0.000367)\end{array}$ & & & $\begin{array}{c}-0.000773^{* *} \\
(0.000340)\end{array}$ & $\begin{array}{c}-0.000643^{* *} \\
(0.000315)\end{array}$ \\
\hline Constant & $\begin{array}{l}10.96^{* * *} \\
(0.0107)\end{array}$ & $\begin{array}{l}10.95^{* * *} \\
(0.0114)\end{array}$ & $\begin{array}{l}10.96^{* * *} \\
(0.0106)\end{array}$ & $\begin{array}{l}10.95^{* * *} \\
(0.0115)\end{array}$ & $\begin{array}{l}10.96^{* * *} \\
(0.0105)\end{array}$ & $\begin{array}{l}10.96^{* * *} \\
(0.0103)\end{array}$ & $\begin{array}{l}10.96^{* * *} \\
(0.0105)\end{array}$ & $\begin{array}{l}10.96^{* * *} \\
(0.0104)\end{array}$ \\
\hline Observations & 120 & 120 & 120 & 120 & 118 & 118 & 118 & 118 \\
\hline R-squared & 0.713 & 0.766 & 0.715 & 0.766 & 0.846 & 0.851 & 0.848 & 0.853 \\
\hline Outliers & Included & Included & Included & Included & Excluded & Excluded & Excluded & Excluded \\
\hline Period & $2013 / 2014$ & $2013 / 2014$ & $2013 / 2014$ & 2013/2014 & $2013 / 2014$ & $2013 / 2014$ & $2013 / 2014$ & $2013 / 2014$ \\
\hline
\end{tabular}

\subsection{Results from the instrumental variables approach}

In order to illustrate how our instruments are good predictors of entry, Table 6 below summarizes the results obtained from the estimation of a Linear Probability Model (LPM), in which the dependent variable is a dummy variable that takes the value of 1 (one) if there is presence of a NG provider in a given municipality and 0 (zero) otherwise. Results suggest that both population size and income have a positive and significant impact on the probability of NG entry. In addition, the distance to Quintero port generates a negative significant impact on the probability of entry. This latter result is intuitive, as a longer distance to the port may generate higher costs of deployment of an NG network and higher distribution costs. Finally, we find a non-significant effect associated to the number of LPG providers in a given municipality. 
Table 6 - Linear Probability Model (municipalities with presence of Lipigas)

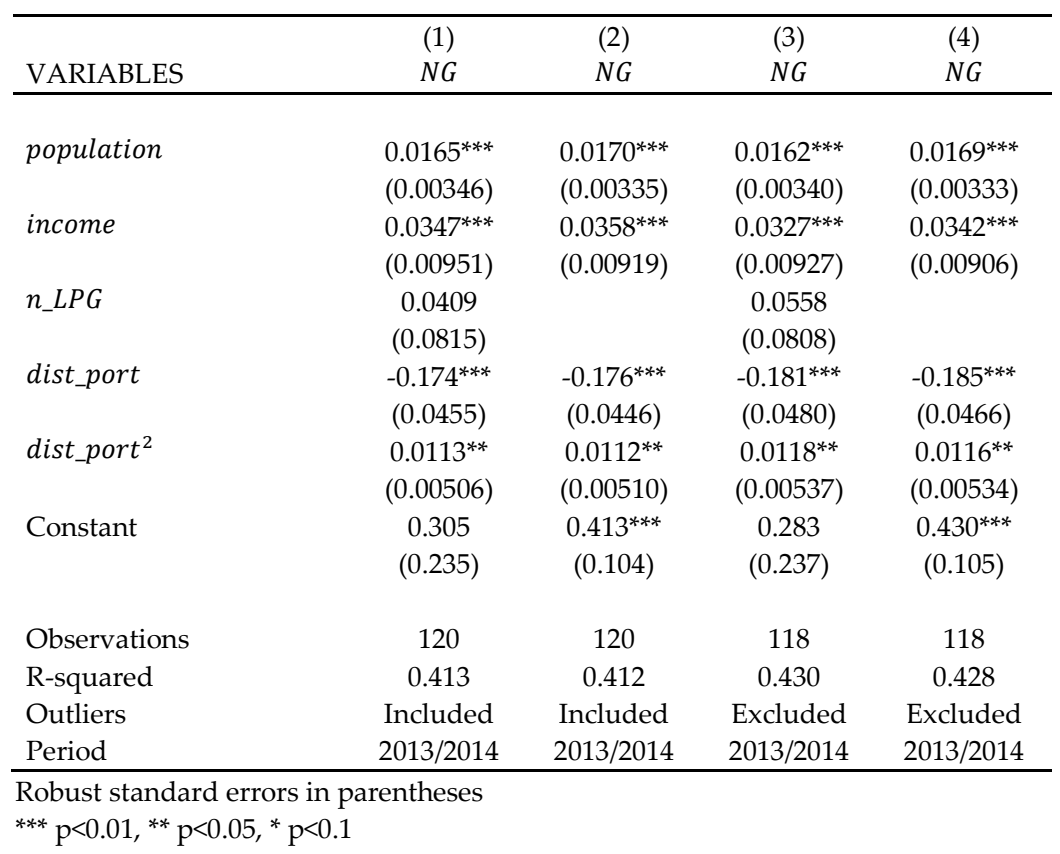

Table 7 displays the results of estimating the pricing equation using population size and income as instruments. This IV approach allows us to control for the potential presence of endogeneity of the entry decision by an NG provider. Columns (1) and (2) only use population size as instrument, while Columns (3) and (4) use both population size and income as instruments.

The entry coefficients (i.e., the variable NG) reported in Columns (1) and (2) are larger (in absolute terms) than the ones displayed in Table 5. Indeed, results obtained through IV suggest an impact of the presence of an NG competing provider on LPG retail prices close to $-4 \%$ on average. Thus, the endogeneity of entry in the cross-section OLS model induces a positive bias on the estimated NG presence coefficients (in other words, an underestimation of these coefficients). This is consistent with the fact that entry of an NG provider may be motivated by profitability considerations. For instance, entry should more likely to occur in larger and richer municipalities, where retail prices may be higher (controlling by other market characteristics). 
Table 7 - Cross section analysis with instrumental variables (Lipigas prices only)

\begin{tabular}{|c|c|c|c|c|c|c|c|c|}
\hline VARIABLES & $\begin{array}{c}(1) \\
\ln (\text { price })\end{array}$ & $\begin{array}{c}(2) \\
\ln (\text { price })\end{array}$ & $\begin{array}{c}(3) \\
\ln (\text { price })\end{array}$ & $\begin{array}{c}(4) \\
\ln (\text { price })\end{array}$ & $\begin{array}{c}(5) \\
\ln (\text { price })\end{array}$ & $\begin{array}{c}(6) \\
\ln (\text { price })\end{array}$ & $\begin{array}{c}(7) \\
\ln (\text { price })\end{array}$ & $\begin{array}{c}(8) \\
\ln (\text { price })\end{array}$ \\
\hline$N G$ & $\begin{array}{c}-0.0473^{* * *} \\
(0.00985)\end{array}$ & $\begin{array}{c}-0.0448^{* * *} \\
(0.00821)\end{array}$ & $\begin{array}{c}-0.0447^{* * *} \\
(0.00750)\end{array}$ & $\begin{array}{c}-0.0405^{* * *} \\
(0.00620)\end{array}$ & $\begin{array}{c}-0.0369^{* * *} \\
(0.00665)\end{array}$ & $\begin{array}{c}-0.0370^{* * *} \\
(0.00652)\end{array}$ & $\begin{array}{c}-0.0364^{* * *} \\
(0.00535)\end{array}$ & $\begin{array}{c}-0.0359^{* * *} \\
(0.00532)\end{array}$ \\
\hline$n_{-} L P G$ & $\begin{array}{c}0.00673 \\
(0.00447)\end{array}$ & $\begin{array}{c}0.00567 \\
(0.00463)\end{array}$ & $\begin{array}{c}0.00663 \\
(0.00435)\end{array}$ & $\begin{array}{c}0.00552 \\
(0.00447)\end{array}$ & $\begin{array}{c}0.00405 \\
(0.00397)\end{array}$ & $\begin{array}{c}0.00395 \\
(0.00389)\end{array}$ & $\begin{array}{c}0.00402 \\
(0.00394)\end{array}$ & $\begin{array}{c}0.00389 \\
(0.00384)\end{array}$ \\
\hline dist_port & $\begin{array}{c}0.00748^{* * *} \\
(0.00211)\end{array}$ & $\begin{array}{l}0.0153^{* * *} \\
(0.00350)\end{array}$ & $\begin{array}{c}0.00768^{* * *} \\
(0.00195)\end{array}$ & $\begin{array}{l}0.0158^{* * *} \\
(0.00351)\end{array}$ & $\begin{array}{l}0.0103^{* * *} \\
(0.00111)\end{array}$ & $\begin{array}{l}0.0120^{* * *} \\
(0.00231)\end{array}$ & $\begin{array}{l}0.0104^{* * *} \\
(0.00106)\end{array}$ & $\begin{array}{l}0.0121^{* * *} \\
(0.00224)\end{array}$ \\
\hline dist_port ${ }^{2}$ & & $\begin{array}{l}-0.00101^{*} \\
(0.000540)\end{array}$ & & $\begin{array}{c}-0.00104^{*} \\
(0.000545)\end{array}$ & & $\begin{array}{c}-0.000233 \\
(0.000294)\end{array}$ & & $\begin{array}{l}-0.000237 \\
(0.000290)\end{array}$ \\
\hline income & $\begin{array}{c}0.000421 \\
(0.000556)\end{array}$ & $\begin{array}{c}0.000721 \\
(0.000555)\end{array}$ & & & $\begin{array}{c}8.14 \mathrm{e}-05 \\
(0.000393)\end{array}$ & $\begin{array}{c}0.000175 \\
(0.000366)\end{array}$ & & \\
\hline Constant & $\begin{array}{l}10.96^{* * *} \\
(0.0125)\end{array}$ & $\begin{array}{l}10.95^{* * *} \\
(0.0133)\end{array}$ & $\begin{array}{l}10.96^{* * *} \\
(0.0122)\end{array}$ & $\begin{array}{l}10.95^{* * *} \\
(0.0127)\end{array}$ & $\begin{array}{l}10.96^{* * *} \\
(0.0113)\end{array}$ & $\begin{array}{l}10.96^{* * *} \\
(0.0114)\end{array}$ & $\begin{array}{l}10.96^{* * *} \\
(0.0112)\end{array}$ & $\begin{array}{l}10.96^{* * *} \\
(0.0113)\end{array}$ \\
\hline Observations & 120 & 120 & 120 & 120 & 118 & 118 & 118 & 118 \\
\hline R-squared & 0.641 & 0.689 & 0.657 & 0.715 & 0.805 & 0.806 & 0.808 & 0.812 \\
\hline Outliers & Included & Included & Included & Included & Excluded & Excluded & Excluded & Excluded \\
\hline Period & $2013 / 2014$ & $2013 / 2014$ & $2013 / 2014$ & $2013 / 2014$ & $2013 / 2014$ & $2013 / 2014$ & $2013 / 2014$ & $2013 / 2014$ \\
\hline Instruments & Population & Population & $\begin{array}{c}\text { Population } \\
\text { Income }\end{array}$ & $\begin{array}{c}\text { Population } \\
\text { Income }\end{array}$ & Population & Population & $\begin{array}{c}\text { Population } \\
\text { Income }\end{array}$ & $\begin{array}{c}\text { Population } \\
\text { Income }\end{array}$ \\
\hline
\end{tabular}

Robust standard errors in parentheses

${ }^{* * *} \mathrm{p}<0.01,{ }^{* *} \mathrm{p}<0.05,{ }^{*} \mathrm{p}<0.1$

In Columns (1) and (2) the coefficients associated to the income variable are not significantly different from zero, which supports its removal from the pricing equation and its inclusion as instrument in Columns (3) and (4). ${ }^{24}$ Finally, all the specifications are replicated but without considering the two outlier observations identified in Figure 2 (i.e., Arica and Calama) and the results are similar, i.e., the estimated effect of the presence of an NG provider on LPG retail prices is close to $-4 \%$ on average (Columns 4 to 8 ).

As shown in Figure 2 of Section 3, Metrogas (i.e., the NG provider of the Metropolitan Region) seems to be significantly more aggressive in pricing than NG providers operating in other regions. Hence, the negative coefficient associated with the presence of an NG provider may be explained exclusively by LPG providers pricing more aggressively in the Metropolitan Region as well, or by the existence of other confounding variables explaining significantly lower prices in this region for both LPG and NG providers simultaneously. As a robustness check, we replicated the IV estimates but only

\footnotetext{
${ }^{24}$ Similarly, Table A.1 in the Appendix replicates the IV estimates using income as instrument in all specifications, and considering population size in the pricing equation. In line with the assumption that population size should not influence the level of retail prices, this coefficient is never significantly different from zero.
} 
considering municipalities outside of the Metropolitan Region. Results are reported in Table A.2 in the Appendix. The coefficient associated with the presence of an NG provider is still negative and significant in all specifications, however their magnitudes are lower, which is consistent with the fact that NG providers out of the Metropolitan Region price less aggressively.

\section{Conclusions and Policy Implications}

The aim of this paper was to empirically assess whether the entry of an NG provider in a particular geographic market had an impact on LPG retail prices. In developing countries, where the penetration of LPG is still high, the entry of NG networks coexists with the use of LPG by an important fraction of households. Thus, a relevant matter for competition authorities is to determine whether the number and degree of horizontal integration among NG and LPG providers influences the level of equilibrium retail prices in the market.

Using data of monthly retail prices at the municipality level self-reported by the largest LPG retail provider in Chile during the period January 2013 - December 2014, we estimate that the presence of an NG provider indeed generates an average reduction of LPG retail prices of about $-4 \%$ on average (in the IV model). This exercise represents an indirect test of the degree of competition between LPG and NG providers. Indeed, in a context of perfect competition between retail providers of gas, the presence of an additional competitor (e.g., an NG provider) should not have any impact on the level of retail prices (as long as there are more than two independent LPG providers in the market). However, in a context of imperfect competition, the presence of an additional competitor (e.g., and NG provider) should have an impact on the level of prices.

Thus, our findings suggest that competition between LPG and NG providers takes place in an imperfect competition setting. The main policy implication of this result is that in general in an industry characterized by the presence of imperfect competition, there should be room for regulatory intervention aimed at evaluating the impact of horizontal 
integration on prices, and at proposing remedies in order to mitigate potential anticompetitive effects.

\section{Appendix}

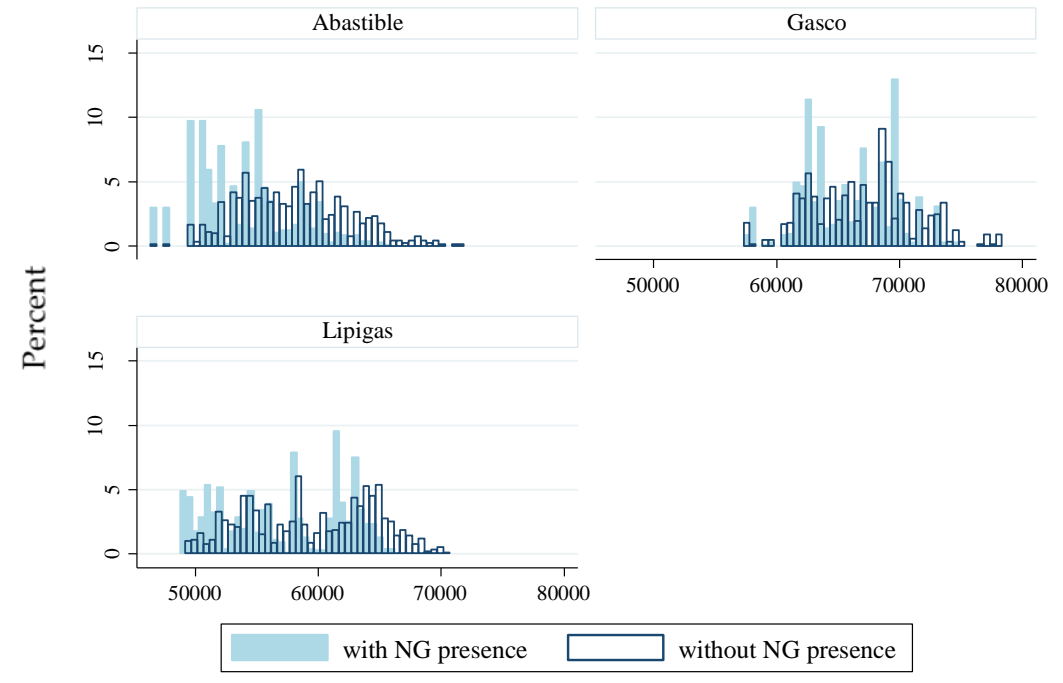

Retail price (Chilean pesos)

(*) The graph only considers municipalities in which the three LPG providers are present

Figure A.1 - LPG prices by municipalities with and without NG presence $\left(^{*}\right)$ 


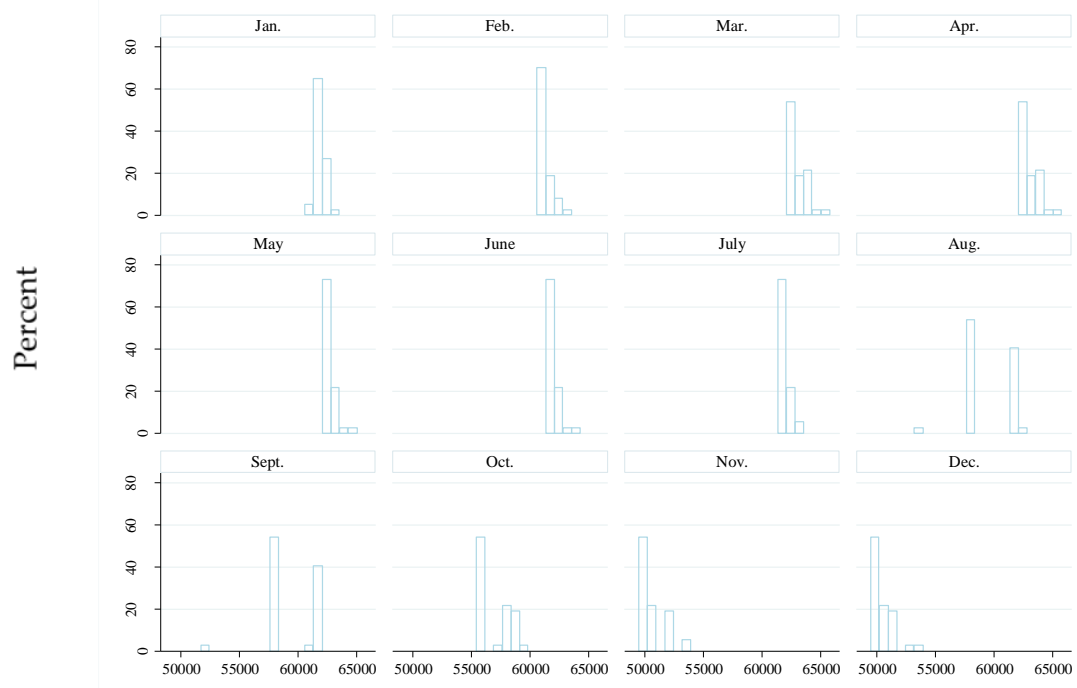

Retail price (Chilean pesos)

Figure A.2 - Lipigas LPG retail prices by municipalities of the Metropolitan Region

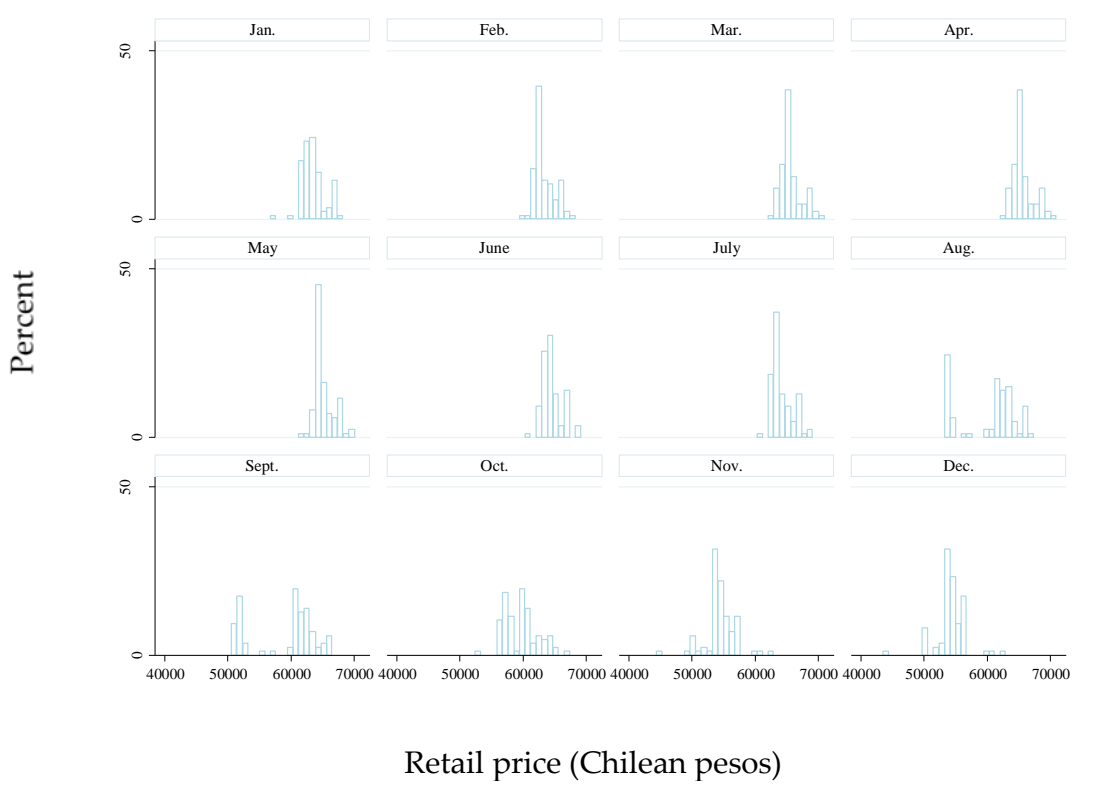

Figure A.3 - Lipigas LPG retail prices by municipalities outside the Metropolitan Region 
Table A.1 - Cross section analysis with instrumental variables, using income as instrument (Lipigas prices only)

\begin{tabular}{lcccc}
\hline VARIABLES & $(1)$ & $(2)$ & $(5)$ & $(6)$ \\
$N G$ & $\ln ($ price $)$ & $\ln ($ price $)$ & $\ln ($ price $)$ & $\ln ($ price $)$ \\
\hline & & & & \\
$n \_L P G$ & $-0.0365^{* * *}$ & $-0.0241^{* *}$ & $-0.0347^{* * *}$ & $-0.0316^{* * *}$ \\
& $(0.00830)$ & $(0.0104)$ & $(0.00792)$ & $(0.00804)$ \\
dist_port & 0.00641 & 0.00482 & 0.00394 & 0.00365 \\
& $(0.00404)$ & $(0.00399)$ & $(0.00390)$ & $(0.00368)$ \\
dist_port ${ }^{2}$ & $0.00844^{* * *}$ & $0.0189^{* * *}$ & $0.0106^{* * *}$ & $0.0129^{* * *}$ \\
& $(0.00163)$ & $(0.00436)$ & $(0.00127)$ & $(0.00263)$ \\
population & & $-0.00125^{* *}$ & & -0.000296 \\
& & $(0.000577)$ & & $(0.000306)$ \\
Constant & -0.000183 & -0.000344 & $-3.52 \mathrm{e}-05$ & $-8.64 \mathrm{e}-05$ \\
& $(0.000222)$ & $(0.000234)$ & $(0.000165)$ & $(0.000168)$ \\
& $10.96^{* * *}$ & $10.95^{* * *}$ & $10.96^{* * *}$ & $10.96^{* * *}$ \\
Observations & $(0.0112)$ & $(0.0124)$ & $(0.0113)$ & $(0.0113)$ \\
R-squared & & & & \\
Outliers & 120 & 120 & 118 & 118 \\
Period & 0.699 & 0.776 & 0.816 & 0.831 \\
Instruments & Included & Included & Excluded & Excluded \\
R & $2013 / 2014$ & $2013 / 2014$ & $2013 / 2014$ & $2013 / 2014$ \\
& Income & Income & Income & Income \\
\hline
\end{tabular}

Robust standard errors in parentheses

*** $\mathrm{p}<0.01,{ }^{* *} \mathrm{p}<0.05,{ }^{*} \mathrm{p}<0.1$

Table A.2 - Cross section analysis with instrumental variables, municipalities out of the Metropolitan Region (Lipigas prices only)

\begin{tabular}{|c|c|c|c|c|c|c|c|c|}
\hline VARIABLES & $\begin{array}{c}(1) \\
\ln (\text { price })\end{array}$ & $\begin{array}{c}(2) \\
\ln (\text { price })\end{array}$ & $\begin{array}{c}(3) \\
\ln (\text { price })\end{array}$ & $\begin{array}{c}(4) \\
\ln (\text { price })\end{array}$ & $\begin{array}{c}(5) \\
\ln (\text { price })\end{array}$ & $\begin{array}{c}(6) \\
\ln (\text { price })\end{array}$ & $\begin{array}{c}(7) \\
\ln (\text { price })\end{array}$ & $\begin{array}{c}(8) \\
\ln (\text { price })\end{array}$ \\
\hline$N G$ & $\begin{array}{c}-0.0381^{* *} \\
(0.0187)\end{array}$ & $\begin{array}{c}-0.0406^{* *} \\
(0.0165)\end{array}$ & $\begin{array}{c}-0.0396^{* *} \\
(0.0154)\end{array}$ & $\begin{array}{c}-0.0366^{* * *} \\
(0.0138)\end{array}$ & $\begin{array}{l}-0.0179 * * \\
(0.00813)\end{array}$ & $\begin{array}{l}-0.0204^{* *} \\
(0.00824)\end{array}$ & $\begin{array}{c}-0.0208^{* * *} \\
(0.00808)\end{array}$ & $\begin{array}{c}-0.0210^{* * * *} \\
(0.00783)\end{array}$ \\
\hline$n_{-} L P G$ & $\begin{array}{l}0.00980^{* *} \\
(0.00460)\end{array}$ & $\begin{array}{c}0.00738 \\
(0.00509)\end{array}$ & $\begin{array}{l}0.00955^{* *} \\
(0.00466)\end{array}$ & $\begin{array}{l}0.00845^{*} \\
(0.00490)\end{array}$ & $\begin{array}{c}0.00597 \\
(0.00395)\end{array}$ & $\begin{array}{c}0.00557 \\
(0.00376)\end{array}$ & $\begin{array}{c}0.00540 \\
(0.00394)\end{array}$ & $\begin{array}{c}0.00530 \\
(0.00375)\end{array}$ \\
\hline dist_port & $\begin{array}{c}0.00845^{* * *} \\
(0.00233)\end{array}$ & $\begin{array}{l}0.0169^{* * *} \\
(0.00325)\end{array}$ & $\begin{array}{c}0.00832^{* * *} \\
(0.00201)\end{array}$ & $\begin{array}{l}0.0169^{* * *} \\
(0.00319)\end{array}$ & $\begin{array}{c}0.0116^{* * *} \\
(0.000857)\end{array}$ & $\begin{array}{l}0.0137^{* * *} \\
(0.00158)\end{array}$ & $\begin{array}{c}0.0113^{* * *} \\
(0.000938)\end{array}$ & $\begin{array}{l}0.0137^{* * *} \\
(0.00161)\end{array}$ \\
\hline dist_port ${ }^{2}$ & & $\begin{array}{l}-0.00115^{* *} \\
(0.000545)\end{array}$ & & $\begin{array}{l}-0.00110^{* *} \\
(0.000512)\end{array}$ & & $\begin{array}{l}-0.000317 \\
(0.000243)\end{array}$ & & $\begin{array}{l}-0.000338 \\
(0.000243)\end{array}$ \\
\hline income & $\begin{array}{r}-0.000700 \\
(0.00332)\end{array}$ & $\begin{array}{c}0.00245 \\
(0.00375)\end{array}$ & & & $\begin{array}{c}-0.00153 \\
(0.00194)\end{array}$ & $\begin{array}{c}-0.000532 \\
(0.00190)\end{array}$ & & \\
\hline Constant & $\begin{array}{l}10.95^{* * *} \\
(0.0126)\end{array}$ & $\begin{array}{l}10.94^{* * *} \\
(0.0153)\end{array}$ & $\begin{array}{l}10.95^{* * *} \\
(0.0123)\end{array}$ & $\begin{array}{l}10.94^{* * *} \\
(0.0136)\end{array}$ & $\begin{array}{l}10.95^{* * *} \\
(0.0115)\end{array}$ & $\begin{array}{l}10.95^{* * *} \\
(0.0114)\end{array}$ & $\begin{array}{l}10.95^{* * *} \\
(0.0111)\end{array}$ & $\begin{array}{l}10.95^{* * *} \\
(0.0108)\end{array}$ \\
\hline Observations & 83 & 83 & 83 & 83 & 81 & 81 & 81 & 81 \\
\hline R-squared & 0.532 & 0.578 & 0.521 & 0.605 & 0.818 & 0.815 & 0.809 & 0.813 \\
\hline Outliers & Included & Included & Included & Included & Excluded & Excluded & Excluded & Excluded \\
\hline Period & $2013 / 2014$ & $2013 / 2014$ & $2013 / 2014$ & $2013 / 2014$ & $2013 / 2014$ & $2013 / 2014$ & 2013/2014 & $2013 / 2014$ \\
\hline Instruments & Population & Population & $\begin{array}{l}\text { Population } \\
\text { Income }\end{array}$ & $\begin{array}{c}\text { Population } \\
\text { Income }\end{array}$ & Population & Population & $\begin{array}{l}\text { Population } \\
\text { Income }\end{array}$ & $\begin{array}{c}\text { Population } \\
\text { Income }\end{array}$ \\
\hline
\end{tabular}

Robust standard errors in parentheses

*** $\mathrm{p}<0.01,{ }^{* *} \mathrm{p}<0.05,{ }^{*} \mathrm{p}<0.1$ 


\section{References}

1. Berry and Waldfogel (1999), "Public radio in the United States: does it correct market failure or cannibalize commercial stations?", Journal of Public Economics $71(1999)$ 189-211

2. Bresnahan, Timothy F., and Peter C. Reiss (1991), "Entry and Competition in Concentrated Markets", Journal of Political Economy, Vol. 99, No. 5 (Oct., 1991), pp. 977-1009

3. Brito, Duarte, Ricardo Ribeiro and Helder Vasconcelos (2014), "Measuring Unilateral Effects in Partial Horizontal Acquisitions", International Journal of Industrial Organization, Volume 33, March 2014, Pages 22-36

4. Brown,S.P.A., and Yücel, M.K. (2008), “What drives natural gas prices?”, Energy Journal 29(2), 45-60.

5. Heckman J., (1979), “Sample Selection Bias as Specification Error”, Econometrica, 47, 153-161

6. Hulshof, Daan, Jan-Pieter van der Maat, and Machiel Mulder (2016), "Market fundamentals, competition and natural-gas prices", Energy Policy 94 (2016) 480491.

7. Kojima, Masami, Robert Bacon, and Xin Zhou (2011), “Who Uses Bottled Gas? Evidence from Households in Developing Countries", Policy Research Working Paper 5731, The World Bank, Sustainable Energy Department

8. Manuszak, M., and C. Moul (2008), “Price and Endogenous Market Structure in Office Supply Superstores", Journal of Industrial Economics, 41(1), 94-112.

9. Market Inquiry into the LPG Sector Final Report (Non-Confidential), March 2017, Competition Commission of South Africa. Report retrieved from the following link: http://www.compcom.co.za/wp-content/uploads/2017/04/LPG-FINAL-NONCONFIDENTIAL-VERSION.pdf

10. Mu, Xiaoyi (2007), “Weather, storage and natural gas price dynamics: fundamentals and volatility", Energy Economics 29(1), 46-63. 
11. Nardotto, Mattia, Tommaso Valletti and Frank Verboven (2015), “Unbundling the Incumbent: Evidence from UK Broadband", Journal of the European Economic Association, 2015 (May 2012), 13(2), 330-362 